\title{
Meteroglyph Analysis for Morphological Variation in Sunflower (Helianthus annuus L.)
}

\author{
G. H. Naik*, M. K. Ghodke, N. R. Thakur and T. A. Chavan \\ Department of Genetics and Plant Breeding, College of Agriculture, Latur-413 512, \\ Vasantrao Naik Marathwada Agricultural University, Parbhani, India \\ *Corresponding author
}

\section{A B S T R A C T}

Keywords

Meteroglyph, Index score, oleic acid

Article Info

Accepted:

22 August 2019

Available Online:

10 September 2019
Sixty-one sunflower multihead inbred lines including one check were evaluated to study the morphological variations for eleven characters by Meteroglyph analysis and index score method. These lines were grouped into four complexes viz., 18 dwarf height with low seed yield per plant (Complex I), 17tall height with low seed yield per plant (complex II), 15dwarf height with high seed yield per plant (Complex III), 11 tall height with high seed yield per plant (Complex IV). The scatter diagram, index scoring and ray pattern showed that beside plant height and seed yield per plant, the genotypes SS-2038, IC-597575, EC-601785, EC640337, IC-438395, EC-601938.TSG-90,TSG-36,TSG-97showed higher morphological variations for more number of traits. Thus the use of these genotypes in future breeding programme is suggested.

\section{Introduction}

Sunflower (Helianthus annuus L.) is one of the most important oil seed crop in India. In India, was taken up in view of its various advantages viz., photo and thermo insensitivity, short duration, high yield and better quality of oil, high oleic acid (20\%), linoleic acid $(70 \%)$, palmitic acid (4.6\%) and stearic acid $(2.3 \%)$. Genetic variability is the basic requirement for crop improvement as it provides wider scope for selection. The success of plant breeding for improving a trait of interest depends on the availability of diverse germplasm, precise selection procedure and crossing programme. There are several methods utilized for the assessment of genetic diversity and grouping of genotypes. Meteroglyph analysis initially given by Anderson (1957) was mainly for establishing relationship among races and biotypes of crop plants. Meteroglyph analysis has been used to access the genetic variability not only in 
sunflower but also in several crop species across the genus. Dewan et al., (1992) in Indian mustard; Chandra et al., (1997) in turmeric; Laiju et al., (2002) in Hordeum species; Ghafoor and Ahmad (2005) in black gram; Bhargava et al., (2009) in Chenopodium; Khan et al., (2007) in 7 cotton cultivars; Rashid et al., (2007) in basmati rice mutants; Kang et al., (2013) in sugarcane cultivar; Jha et al., (2011) in chickpea and Datta et al.,(2013) in maize used this method to assess the morphological variations.

Thus, the present experiment was conducted with an aim to evaluate the morphological variation of 61 sunflower genotypes for eleven yield and yield component characters by Meteroglyph analysis and to develop a selection criterion.

\section{Materials and Methods}

The experimental material comprising 61 Multihead inbred lines of sunflower were grown during kharif2017 in a Randomized Block Design with two replications at the Experimental Farm, Oilseeds Research Station, Latur.

Data were recorded on three randomly tagged plants for days to $50 \%$ flowering, days to maturity, plant height $(\mathrm{cm})$, head diameter (cm), number of branches per plant, seed filling (\%), hull content (\%),100 seed weight $(\mathrm{g})$, oil content $(\%)$, seed yield per plant $(\mathrm{g})$, volume weight $(\mathrm{g}) / 100 \mathrm{ml}$.

Data were subjected to the analysis of variance followed by Anderson's Meteroglyph technique to study the patterns of morphological variations in different genotypes.

All genotypes represented by open glyph. Two most variable characters, plant height and seed yield per plant were selected for $\mathrm{X}$ and $\mathrm{Y}$ axis, respectively. Except these traits other traits were represented as rays on the glyph, where each glyph represented a genotype thus forming a scatter diagram.

\section{Results and Discussion}

The analysis of variance indicated significant variations among the sixty-one inbred lines for eleven characters. The scatter diagram revealed that four complexes could be distinguished on the basis of morphological variation (Fig.1 and Table 1). The Index scores and signs used for nine characters for Meteroglyph analysis were presented in Table 2.

Complex I was characterized dwarf height with low seed yield per plant this group comprised 18 lines. The Complex II was containing 17 lines and characterized by tall height with low seed yield per plant.

Dwarf height with high seed yield per plant was included in complex III. This complex comprised 15 lines. And fourth complex was characterized by tall height with high seed yield per plant which includes 11 lines.

The frequency diagram revealed that the index scores ranged from 15 to 27 (Fig. 2). Eleven genotypes recorded index score of 21 followed by $8,7,7,7$ genotypes with an index score of 23,20,25,24 respectively. Minimum frequency of genotypes (1) occurred for index score of 15 and 17. Highest index score of 27 recorded by four lines.

The scatter diagram, index scoring and ray pattern showed that beside plant height and seed yield per plant, the genotypes, SS-2038, IC-597575, EC-601785, EC-640337, IC438395, EC-601938. TSG-90, TSG-36, TSG97 showed higher morphological variations for more number of traits. Thus, the use of these genotypes in future breeding programme is suggested. 
Table.1 Complex constellation based on Meteroglyph analysis

\begin{tabular}{|l|l|l|l|}
\hline $\begin{array}{l}\text { Comple } \\
\mathbf{x}\end{array}$ & $\begin{array}{l}\text { Name of } \\
\text { complex }\end{array}$ & $\begin{array}{l}\text { No. of } \\
\text { lines }\end{array}$ & Name of lines \\
\hline I & $\begin{array}{l}\text { Dwarf height } \\
\text { with low seed } \\
\text { yield per plant }\end{array}$ & 18 & $\begin{array}{l}\text { EC-399490, EC-494380, EC-512738, EC-399621, EC- } \\
512711, \text { EC-399512, EC-494356, EC-512685, EC-494399, } \\
\text { EC-512693, EC-512678, TSG-71, TSG-107, EC-640350, } \\
\text { EC-601744, EC-494427, EC-601612, TSG-84, EC-601875 }\end{array}$ \\
\hline II & $\begin{array}{l}\text { Tall height with } \\
\text { low seed yield } \\
\text { per plant }\end{array}$ & $\begin{array}{l}\text { IC-494364, IC-501988, EC-601935, TSG-19, EC-602064, } \\
\text { EC-640358,EC-512724,TSG-07,TSG-36, EC-601988, EC- } \\
\text { III }\end{array}$ & $\begin{array}{l}\text { Do1890, EC-601932, EC-620191, EC-640337, EC-601938 } \\
\text { IC-438395, TSG-108 }\end{array}$ \\
\hline $\begin{array}{l}\text { with high seed } \\
\text { yield per plant }\end{array}$ & 15 & $\begin{array}{l}\text { EC-494389, EC-494396, EC-601676, EC-640327, EC- } \\
\text { 494380, EC-399622, EC-601655, EC-512758, EC-640332, } \\
\text { TSG-37, EC-601759, EC-601846, EC-512709, EC- }\end{array}$ \\
\hline $\begin{array}{l}\text { IV } \\
\text { Tall height with } \\
\text { high seed yield } \\
\text { per plant }\end{array}$ & 11 & $\begin{array}{l}\text { EC-601785, EC-601836, EC-601771, TSG-97, EC- } \\
601970, \text { TSG-90, SS- 2038, IC-597575, EC-601885, EC- } \\
\text { 601974, EC-601906 }\end{array}$ \\
\hline
\end{tabular}

Table.2 Index scores and signs used for nine characters under Meteroglyph analysis

\begin{tabular}{|c|c|c|c|c|c|c|}
\hline character & Score 1 & - sign & Score 2 & sign & Score 3 & sign \\
\hline & Value < & & Value from -to & & Value $>$ & \\
\hline Days to $50 \%$ flowering & 54.55 & 0 & $54.55-59.6$ & 8 & 59.6 & $\delta$ \\
\hline Days to maturity & $87: 66$ & 0 & $87.66-97.32$ & $\sigma$ & 97.32 & \\
\hline head diameter $(\mathrm{cm})$ & 14.1 & 0 & $14.1-20.3$ & 0 & 20.3 & $0-$ \\
\hline No of branches per plant & 2.038 & 0 & $2.038-4.06$ & Q & 4.06 & \\
\hline Seed filling (\%) & 64.66 & 0 & $64.66-74.86$ & $Q$ & 74.86 & \\
\hline hull content $(\%)$ & 27.05 & 0 & $27.05-35.1$ & 0 & 35.1 & \\
\hline 100 seed weight $(\mathrm{g})$ & 3.78 & 0 & $3.78-4.98$ & -0 & 4.98 & \\
\hline oil content (\%) & 29.19 & 0 & $29.19-32.56$ & 0 & 32.56 & \\
\hline volume weight (g) & 45.14 & 0 & $45.14-37.16$ & $b$ & 55,8 & \\
\hline
\end{tabular}




\section{Int.J.Curr.Microbiol.App.Sci (2019) 8(9): 2359-2364}

Fig.1 Scatter diagram of Meteroglyph analysis for 61 sunflower inbred lines.

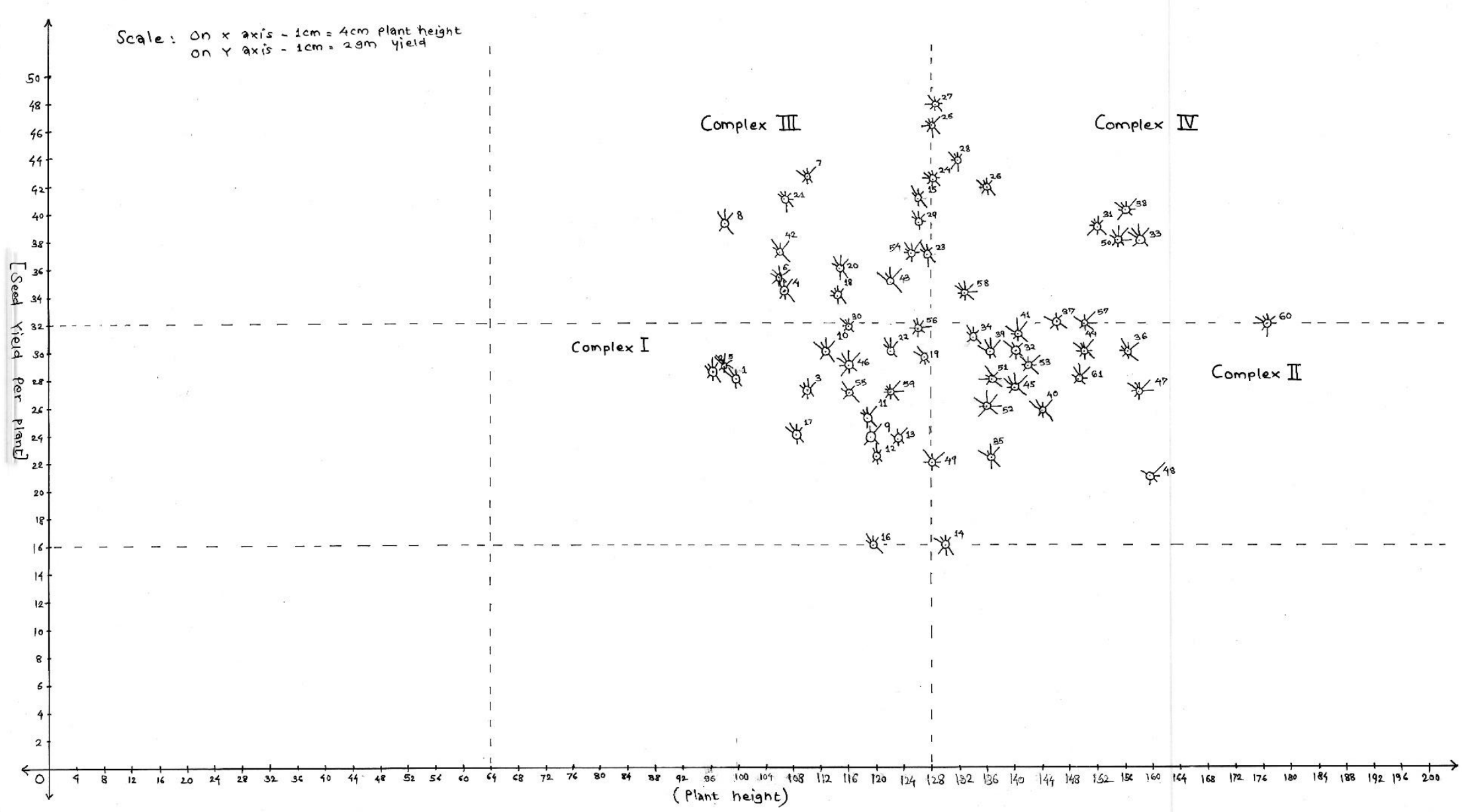


Fig.2 Frequency diagram

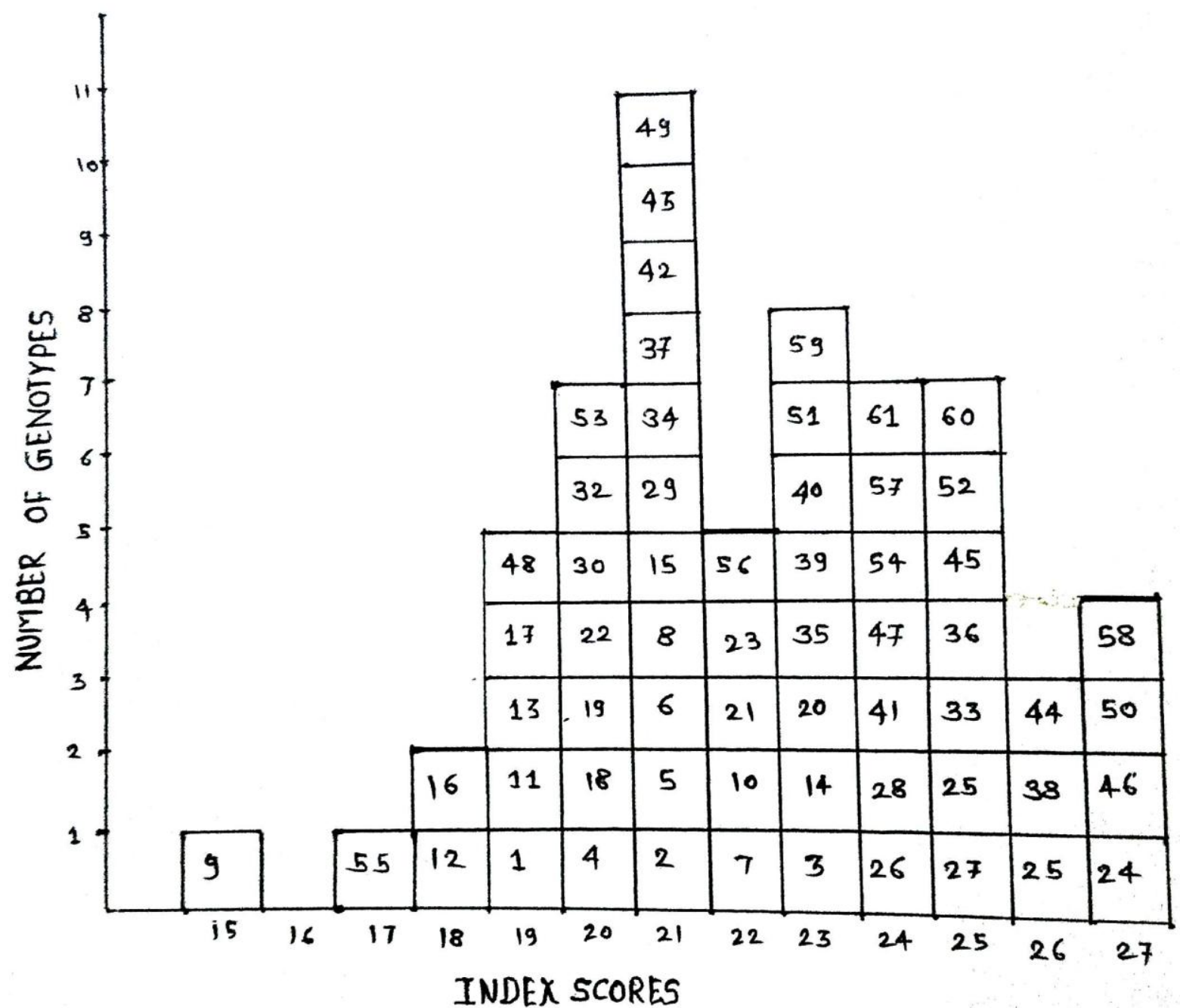

\section{References}

Anderson E. 1957. A semigraphical method for the analysis of complex problems. Proc. Nat. Acad. Sci. U.S.A. 43:923927.

BhargavaA, Shukla S, Kumar R, and Ohri D. 2009. Meteroglyph Analysis of Morphological Variation in Chenopodium spp. World Journal of AgriculturalScience.5:117-120

Chandra R, Desai AR, Govind S and Gupta PN. 1997. Meteroglyph analysis in turmeric (Curcuma longa L.) germplasm in India.Scientia Horticulturae.12:211-222.
DewanDB, Islam MA and Khaleque MA. 1992. Meteroglyph analysis of morphological variation in Indian mustard (Brassica junceaL.). Agricultural Science.62:766-777.

Ghafoor A and Ahmad Z. 2005. Diversity in black gram (Vigna mungo L. Hepper) for Agronomic traits and total seed proteins analysis. Acta BiologicaCracoviensia Series Botanica47:1-7.

Jha UC, Singh DP, Paul PJ and G Roopa L.2011. Meteroglyph analysis for morphological variation in Chickpea (Cicer arietinum L.). Madras Agricultural. Journal.98:121-123. 
Khan MR, Samad A, Begum S, KhaledaS, Alam AKMS, Chowdhury AN and Rahman MZ. 2007. Meteroglyph Analysis in Cotton (Gossypium Sp.). Bangladesh Journal of Science and Research.42:449-454.

Kang SA, Muhammad N, Farooq AK, Frasat S.2013. Divergence analysis and association of some economical characters of sugarcane (Saccharum officinaruml.) Journal of Plant
Breeding and Genetics. 1:1-6

Kaur M and Singh N. 2005. Studies on functional, thermal and pasting properties of flours from different chickpea (Cicer arietinum L.) cultivars. Food Chemistry91: 403-411.

Thakur, NR., Toprope, V. N. and Koppuravuri Sai Phanindra. 2018. Metroglyph analysis for morphological variation in Chickpea (Cicer arietinum L.). J. Res. ANGRAU. 46(2) 52-57.

\section{How to cite this article:}

Naik, G. H., M. K. Ghodke, N. R. Thakur and Chavan, T. A. 2019. Meteroglyph Analysis for Morphological Variation in Sunflower (Helianthus annuus L.). Int.J.Curr.Microbiol.App.Sci. 8(09): 2359-2364. doi: https://doi.org/10.20546/ijcmas.2019.809.272 